Original scientific paper

UDK: $316.334 .3: 323(497)$

DOI: $10.5937 /$ jrs 15-25359

Received: 24 February 2020 / Accepted: 13 April 2020

\title{
The Anxiety Dilemma: Locating the Western Balkans in the Age of Anxiety*

\author{
JELENA CUPAĆ**
} \\ WZB-Berlin Social Science Center, Germany
}

\begin{abstract}
The paper seeks to locate the Western Balkans in the current age of anxiety. By using the concept of ontological security as its overarching theoretical frame, the paper first develops a concept of anxiety dilemma. The anxiety dilemma refers to a situation in which a social order that provides one group of people with a sense of ontological security is a perceived source of anxiety for the other group and vice versa. The paper proposes that such a dilemma characterizes the present age of anxiety. Trapped in this dilemma are the proponents and the contesters of the liberal (international) order and globalization, often referred to in the literature as cosmopolitans and communitarians. The paper argues that the Western Balkan countries occupy an ambivalent position in this anxiety dilemma. Their governments combine liberal-democratic justification with autocratic tendencies. The paper discusses how the Western Balkans came to occupy this position. It singles out four reasons: (1) the region's authoritarian legacy; (2) ethnonationalism coupled with state- and nation-building projects; (3) search for external legitimacy; and (4) the EU's abandonment of the inextricable link between peace and democracy. The case of the Western Balkans yields another important observation: that local anxiety dilemmas are nested in global anxiety dilemma. The paper makes two contributions. The first one is theoreti$\mathrm{cal}$, and it consists of furthering the concept of ontological security such that it theorizes ontological security as a systemic inter-group phenomenon. The second contribution is analytical, and it consists in locating the Western Balkans in the ongoing struggles over globalization and the liberal (international) order.
\end{abstract}

Keywords: anxiety dilemma, ontological security, communitarians, cosmopolitans, Western Balkans

\footnotetext{
* The author would like to thank editors and the anonymous reviewer for constructive comments, as well as to Irem Ebetürk and Hendrik Shopmans who read and commented on the paper's earlier version. Thanks also goes to Julia Fuß, Robert Benson, Matthew Stephen, and Jacob Angeli, who, together with Hendrik Shopmans, helped the author name the paper's central concept.

*jelena.cupac@wzb.eu
} 


\section{Introduction}

The liberal international order and democracy are under pressure. The headlines are filled with stories about the rise of populist leaders and far-right parties. There are the usual suspects, the Alternative for Germany, the League in Italy, and the National Front in France. Then, there are less prominent cases, such as the Swedish Democrats, the Conservative People's Party of Estonia, and Vox in Spain. In Hungary and Poland, conservatives have already gained power, and are causing notable damage to the rule of law. The United Kingdom has left the EU. Donald Trump is seeking the second term in office. Erdogan's Turkey and Putin's Russia have become even more authoritarian. Right-wing transnational movements, anti-globalization groups, conservative NGOs, and religious fundamentalists are also on the rise, railing against what they see as the elitist and exploitative foundations of the global liberal script. All of these actors question several or all of the following: the notion of universal human rights and the free movement of goods, capital, and people. They argue for the centrality of national borders, and they question the authority of international organizations.

How do the Western Balkan states ${ }^{1}$ fit into this picture? Following the downfall of communism in the early 1990 s, they were all slow to democratize. Their ruling parties were either offshoots of the League of Communists of Yugoslavia (as in Serbia, Montenegro, and North Macedonia) or newly formed nationalist parties (as in Croatia and Bosnia). Regardless of their origin, most of these parties maintained a firm grip on state institutions. They engaged in election manipulation, strategic privatization, media control, and pressure campaigns against opposition and civil society. Some even pursued war.

In the late 1990s, things started to change. The nation and statehood projects that rested on a combination of authoritarianism and nationalism gave way to genuine (if sluggish) democratization. All of the countries adopted pro-European orientation, with Croatia joining the EU in 2013. It seemed that the region was catching up with the rest of Europe. But how is it positioned to it now? Is it contributing to the trend of democratic decline, or is it still committed to the process of democratization and corresponding integration into the liberal international order?

The paper addresses this question by employing the anxiety frame as it is developed in the literature on ontological security. This frame is chosen in order to capture the unpredictable transformation the world is currently undergoing. The global order that emerged following the end of the Cold War is changing, but we still do not know what kind of order will replace it. In short, we are living in the age of anxiety, and the paper aims at better

1 The Western Balkans label usually refers to the following countries: Croatia, Bosnia and Herzegovina, Serbia, Montenegro, North Macedonia, Albania, and Kosovo. However, this paper will focus on all of these countries except Croatia. Croatia joined the EU in 2013, and the paper sees it as politically belonging to a different region. Its anxieties are now a part of the context that differs significantly from the context in which the remaining Western Balkan states operate, and it thus warrants different treatment. 
understanding the place of the Western Balkans in it. The region has come into existence as a belated brainchild of the post-cold war Euro-Atlantic community, and it is crucial that we understand its position now when the fundamental values of this community are being put to the test.

The paper starts by developing the concept of the anxiety dilemma. The anxiety dilemma refers to a situation in which a social order that provides one group of people with a sense of ontological security is a perceived source of anxiety for the other group and vice versa. One such dilemma, I argue, constitutes the present age of anxiety. It emerges as a consequence of a new social and ideological cleavage developing globally, namely, the cleavage between cosmopolitans (who are sympathetic to globalization and the liberal international order underpinning it) and communitarians (who find this order threatening). ${ }^{2}$ Different groups, states, and regions position themselves differently with respect to this cleavage, that is, with respect to the anxiety dilemma it spurs. They can belong to one of the poles, they can be neutral (not belong to any of the poles), or they can be ambivalent (occupy both poles simultaneously).

The Western Balkans belongs to the latter group. It stands on both ends of the present-day anxiety dilemma. The pro-European orientation and liberal-democratic justification of its governments place it in the cosmopolitan camp. However, their populist, authoritarian, and nationalist tendencies push it in the opposite direction, towards the communitarian camp. The paper suggests four reasons for this ambivalent position: (1) the region's authoritarian legacy; (2) ethnonationalism coupled with state- and nation-building projects; (3) search for external legitimacy; and (4) the EU's seeming abandonment of the inextricable link between peace and democracy. Finally, the paper observes that the current Western Balkan governments are also engaged in the production of local anxiety dilemmas that likewise feed into their position in the global anxiety dilemma. In other words, local anxiety dilemmas seem to be nested in global anxiety dilemmas.

The paper seeks to make two contributions. The first one is theoretical, and it concerns ontological security literature. In discussing current trends, this literature mostly focuses on communitarians and their identity-based responses to contemporary anxieties. ${ }^{3}$ Some works also look at the anxieties of "cosmopolitan" agents such as the EU, NATO, and Brexit "remainers." ${ }^{4}$ However, little work is done on the anxiety dynamics that emerges

2 The literature captures this cleavage with different labels: cosmopolitans versus communitarians (Teney et al. 2014); universalism versus particularism (Beramendi et al. 2015); libertarian-universalistic versus traditionalist-communitarian (Bornschier 2010); demarcation versus integration (Kriesi et al. 2006; 2012).

3 For examle, see: Kinnvall 2019; Kinnvall 2018; Kinnvall 2004; Kinnvall and Nesbitt-Larking 2011; Steele and Homolar 2019; Homolar and Scholz 2019; Gülsah Çapan and Zarakol 2019; Browning 2019.

4 For examle, see: Browning 2018; Mitzen 2018; Dingott Alkopher 2018; Mälksoo 2019 and 2018; Rumelili 2018. 
between the two groups. ${ }^{5}$ The concept of the anxiety dilemma is aimed at filling this gap. It conceptualizes anxiety as an inter-group phenomenon-as a function of the quarrel between cosmopolitans and communitarians over a desired social order. The concept of ontological security is thus employed for the purpose of systemic theorizing and, as such, it is brought into communication with the burgeoning literature on the global democratic decline. The paper's second contribution is analytical. It observes that the Western Balkans is not just another case of democratic backsliding, but that there are specificities that put it in a distinctive relationship with the ongoing global trends. This might also be the case for other groups, states, and regions, and this paper's analytical framework might help identify it.

The paper proceeds in four steps. First, it defines anxiety by relying on the concept of ontological security. In particular, it discusses anxiety-inducing and anxiety-alleviating factors. The second part of the paper uses this discussion to develop the concept of the anxiety dilemma as the defining feature of the current age of anxiety. The third part locates the Western Balkans at both ends of this dilemma and discusses reasons for how the region came to occupy such a position. The fourth and final part of the paper takes a closer look at the Western Balkans' local anxiety dilemmas, arguing that they, too, are a factor that contributes to the region's overall position in the present age of anxiety. The conclusion summarizes the paper's argument, discusses its contribution, and sketches further avenues of research.

\section{Ontological Security and Anxiety}

More and more IR scholars are turning to socio-psychological concepts to study world politics. ${ }^{6}$ The rationalist models, they argue, rest on a simplistic and largely inaccurate understanding of human nature. More attention, therefore, should be paid to various other emotional and cognitive tendencies involved in human behavior. ${ }^{7}$ Anxiety is one such tendency. Etiologically, anxiety derives from Indo-Germanic root Angh, which refers to "narrowing, constricting, and tightening feelings, usually in the chest and throat." However, anxiety is not only about bodily sensations. It is also about intense feelings of worry, dread, dismay, powerlessness, and uneasiness. Anxiety, in other words, is a generalized state of uncertainty and insecurity.

In International Relations, anxiety has most thoroughly been studied by ontological security scholars. ${ }^{9}$ They have examined its causes, manifestations, and alleviation strategies.

5 An exception is Della Sala 2018.

6 Cupać 2018.

7 See special issues in: International Theory (Volume 6, Issue 3, 2014) and International Organization (Volume 71, supplements S1, 2017).

8 Horwitz 2013, 5.

9 For overview, see: Kinnvall and Mitzen 2017. 
Anthony Giddens, who has influenced this scholarship significantly, defines ontological security as a "confidence that most human beings have in the continuity of their self-identity and in the constancy of the surrounding social and material environments." ${ }^{10}$ Ontologically secure actors (individuals, as well as groups) have a sense of existing as a continuous and unchanging person in time, a sense supported by the ordered and predictable environment. ${ }^{11}$ They operate with stable cognitive and emotional frames, which allow them to "define and pursue their interests, build their communities, and act strategically"12 In short, ontologically secure individuals and groups know their place in the world, and they know how to act in it.

They are also unlikely to experience high levels of anxiety given that anxiety is the very opposite of ontological security. ${ }^{13}$ Anxiety results from ontological security being undermined by some traumatic event or a crisis. In effect, it amounts to a sense of ontological insecurity. It emerges once there is a decline in the fundamental belief that the social environment will reproduce as expected. It is a "disruption to routines, which invokes instability and a break with what is knowable, consistent and comprehensible to the self." ${ }^{\prime 14}$ Anxious individuals and groups struggle to grasp their reality in a cognitively and emotionally coherent way. They have difficulties to continue as their "old selves" because routines and "biographical narratives" that were once a part of their everyday life no longer apply. ${ }^{15}$

Anxiety should be distinguished from fear. Fear, argues Giddens, "is a response to a specific threat and therefore has a definite object."16 Usually, it is a reaction to a physical threat. By contrast, anxiety "is a generalized state of the emotions of the individual," resulting from their destabilized identity and social relations. ${ }^{17}$ It emerges when agents are overwhelmed by the uncertainty of external conditions; when they have not yet ordered and grasped pieces of their environment such that they can get by with a sufficient amount of predictability.

Anxiety is intensely uncomfortable. It prompts both individuals and groups to seek strategies to alleviate it, to (re)capture a sense of ontological security. A particularly common and effective strategy is the reaffirmation of self-identity through narratives that locate the Self in a specific time and place. ${ }^{18}$ Such narratives create stable cognitive frames through which individuals and groups can comprehend, order, and process events and social interactions. ${ }^{19}$ Identity, argues Erik Erikson, represents an anxiety-controlling mechanism with which trust, predictability, and a sense of control can be fostered in the face of disruptive social transformations..$^{20}$

However, identity-based strategies of anxiety alleviation often produce problematic consequences. Particularly challenging are situations in which collective actors seek to stabilize their identity by drawing a clear boundary between "us" and "them," or between "friends" and "enemies." To capture this dynamic, scholars often use the concept of securitization;

19 Browning 2018, 339. 
that is, of the "securitization of subjectivity" and the securitization of Other. ${ }^{21}$ The securitization of subjectivity occurs when a group links its sense of anxiety to a threat from another group (e.g., immigrants) or a social process (e.g., globalization). Once enough anxiety is generated, the group tends to respond defensively, adopting an essentialized notion of collective identity. ${ }^{22}$ The group becomes more inward-looking, convinced that their identity rests on solid grounds and truth. ${ }^{23}$ The securitization of subjectivity always involves Other-securitization. The ingroup portrays the religious, cultural, and social identity of the outgroup in an equally essentialized way. However, these portrayals are typically negative, resting on xenophobic and racist attitudes. ${ }^{24}$ Having members of the outgroup nearby, or just considering the possibility of them coming near, increases ontological insecurity of the ingroup as it feels its way of life might disappear.

Identity securitization is not the only anxiety-alleviating strategy. It is, as Jenifer Mitzen puts it, a maladaptive strategy, one that undermines rather than strengthens the security of the Self and the Other. ${ }^{25}$ However, there are strategies of anxiety alleviation with less harmful effects. Their main characteristic is that actors who use them do not interpret identity difference as a security threat. ${ }^{26}$ Instead, they mitigate anxiety by emphasizing such concepts as friendship, trust, respect, and cooperation. Therefore, ontological security and anxiety do not depend on the existence of identity difference, but on how actors handle the difference. Actors can overemphasize a small difference and thus induce intense anxiety, and vice versa, they can downplay big difference and ensure ontological security. ${ }^{27}$

Ontological security scholarship has identified various anxiety-alleviation strategies, often linking them to desecuritization. ${ }^{28}$ While Lene Hansen did not make this link explicitly, the four desecuritisation strategies she proposes correspond well with the current developments in the Western Balkans; hence I summarize them here. ${ }^{29}$ The first strategy is change through stabilization. ${ }^{30}$ It occurs when conflicting parties slowly abandon a precarious security discourse, thereby creating more space for political engagement. A precondition of this strategy is that the parties recognize each other as legitimate. Although it can sometimes lead to conflict resolution, typically, this strategy only moves an anxietyinducing issue into the background where it will stay for as long as the parties are willing

21 For example, see: Kinnvall 2004; Dingott Alkopher 2018 and 2015.

22 Kinnvall and Mitzen 2017; Kinnvall and Nesbitt-Larking 2011.

23 Kinnvall 2004, 274.

24 Dingott Alkopher 2018.

25 Mitzen 2006a.

26 Browning and Joenniemi 2017 and 2013.

27 Blok 1998, 33.

28 See: Browning and Joenniemi 2013; Dingott Alkopher 2015;2018.

29 Hansen 2012.

30 Ibid., 539-540. 
to accommodate the arrangement. The second strategy Hansen identifies is replacement. ${ }^{31}$ It involves removing one issue from the security agenda while simultaneously securitizing another. Hansen's third strategy is rearticulation. ${ }^{32}$ It consists of political actors seeking and offering specific political solutions to threats and conflicts. It is a genuine, radical, and direct strategy that, unlike change through stabilization, does not push the conflict into the background; and, unlike replacement, does not rest on one securitized issue being substituted by another. The final anxiety-alleviating strategy Hansen identifies is silencing..$^{33}$ It occurs when an issue disappears from the security agenda or fails to register on it altogether. It often takes the form of exclusion whereby specific agents are prevented from articulating their security concerns. Before refereeing to these types of anxiety-alleviation to make sense of the ongoing processes in the Western Balkans, it needs to be emphasized that while scholars tend to see de-securitization as desirable, Hansen is more cautious. She warns that, in specific contexts, each of her types can have negative consequences. The ensuing theoretical and empirical discussion will support this position.

\section{The Anxiety Dilemma: Defining the Present-Day Age of Anxiety}

To locate the Western Balkans in the current age of anxiety, we first need to define this age. A possible way of doing so would be to list all the various actors currently contesting the liberal (international) order-e.g., populists, authoritarian regimes, right-wing movements, anti-globalists, conservative NGOs, and religious fundamentalists. By using the concept of ontological security, we could then observe that these actors are disrupting social order, both domestic and international, that, for a very long time, provided many people with stability. These people were able to pursue their interests, build communities, and act strategically in a highly predictable way. Now, however, the trust that their environment is stable and that they can continue as before is dissolving, and it is making them anxious.

However, this approach to defining the current "age of anxiety" would be problematic. It would be one-sided and liberally-biased. It would look at the world and account for the emotional state of only those for whom the liberal order was a source of ontological security while failing to capture those for whom this was not the case. In theoretical terms, it would fail to observe that a social order that provides one group of people with a sense of ontological security can be a source of anxiety for the other group, as well as that the strategies one group employs to grasp their environment and act in it can be profoundly disorienting and anxiety-inducing for the other group.

This dynamic suggests that in societies, including global society, in which there is little consensus on how to order social life, the anxiety dilemma can develop. The concept of

\footnotetext{
31 Ibid., 541-542.

32 Ibid., 542-544.

33 Ibid., 544-545.
} 
anxiety dilemma draws on the concept of security dilemma in that it recognizes that the relationship between two groups can produce an inverted sense of security: the safer one group feels, the less safe the other will feel. The difference between the two dilemmas is in the kind of security involved. In the security dilemma, the focus is on physical security; in the anxiety dilemma, it is on ontological security. The anxiety dilemma should also be differentiated from Mitzen's discussion of the ontological security underpinning the security dilemma. ${ }^{34}$ The difference is that Mitzen focuses on the sense of ontological security arising from the routinization of the security dilemma, whereas the anxiety dilemma captures the seesaw effect of ontological insecurity.

I argue that the anxiety dilemma is a defining feature of the present age of anxiety. The literature examining the causes of the current contestation of the liberal (international) order offers a good, if simple, conceptual vocabulary that can help us describe this dilemma more robustly. This literature maintains, implicitly or explicitly, that in recent decades a new cross-cutting cleavage has emerged, one between cosmopolitans and communitarians. ${ }^{35}$ The chief driver of this cleavage is globalization. For one group of people, who came to adopt a more cosmopolitan worldview, globalization has provided mostly benefits and, by extension, a sense of ontological security. By being embedded in the liberal international order, globalization has not only provided them with economic benefits and cultural capital but also with their preferred system of values expressed through such phenomena as multilateralism, democracy, feminism, and multiculturalism. In short, those with cosmopolitan leanings tend to be globalization winners. In the globalized world, they know who they are and how to act.

By contrast, those who are globalization losers tend to have, or adopt over time, a more communitarian worldview. Globalization has not been accommodating to their parochial identities, value systems, and skills. ${ }^{36}$ It has moved too fast too soon, leaving them disoriented and, in turn, ontologically insecure and anxious. The postindustrial transformation accompanying globalization has created an environment that threatens them existentially. The working conditions are increasingly precarious, and many people lack the skill to navigate this reality. Many are also dissatisfied with the increasingly unequal distribution of wealth. Additionally, systems of values that have proliferated globally, such as feminism and multiculturalism, do not align with the communitarian sense of identity. All this makes communitarians anxious, unable to make sense of their environment and to act in it with purpose. Against this background, mobilizing around populists, authoritarians, right-wing parties and movements, conservative NGOs, and religious fundamentalists can, in part, be interpreted as their anxiety-alleviating strategy. However, it is, to echo Mitzen, a maladaptive strategy. While it creates a world that is easier for them to grasp

\section{Mitzen 2006b.}

35 For example, see: Kriesi et al. 2008; Kriesi et al. 2012; Gilens and Page 2014; Manow 2018; Mouffe 2018; Inglehart and Norris 2016; Mudde and Kaltwasser 2012.

\section{Kinnvall 2004.}


cognitively and behaviorally, it adds fuel to the anxiety dilemma in which they are trapped with cosmopolitans.

Ontological security scholars provide valuable insights into the anxieties of communitarians. In 2004, Catarina Kinnvall made a compelling connection between uncertainties brought on by globalization and the ontological insecurity of certain individuals and groups. She was among the first ones to observe that evoking collective identity, particularly religious and national identity, is one of the most common strategies for reducing anxieties caused by globalization processes. ${ }^{37}$ Recently, several studies have employed the concept of ontological security to account for the rise of populism. Some focus on populism generally, ${ }^{38}$ others look at concrete cases such as Trump's narratives, ${ }^{39}$ Erdogan's populism, ${ }^{40}$ Modi's nationalism, ${ }^{41}$ and Brexit "leavers." ${ }^{42}$ Some studies also look at the anxieties of groups that can be defined as cosmopolitans. They explore Brexit "remainers," EU migration governance, ${ }^{44}$ the EU and NATO's struggle with hybrid warfare ${ }^{45}$ the European anxiety over the return of "Eastern Europe," ${ }^{46}$ and memory politics in the EU. ${ }^{47}$

Despite the richness of these studies, most gloss over the anxiety dynamics between communitarians and cosmopolitans. An exception is Vincent Della Sala's study of the EU narratives. ${ }^{48} \mathrm{He}$ observes that the EU's search for ontological security through foundational narratives and narratives of unity can threaten Russia's and member states' ontological security, respectively. Della Sala describes this situation as "a sort of ontological security dilemma." ${ }^{49} \mathrm{He}$, therefore, captures a phenomenon very similar to the one this paper is seeking to describe. The difference is in the scale and the perspective. While this paper sees the dilemma as a systemic phenomenon unfolding both globally and domestically, Della Sala focuses primarily on the EU and its internal and external relations. In other words, he does not conceptualize dilemma as a consequence of the cross-cutting polarization engulfing the globe at the moment, but as the EU specific phenomena. This approach is also a likely reason Della Sala opts to label the dilemma as "the ontological security dilemma" rather than "the anxiety dilemma." His focus is more on the repercussions

37 Kinnvall 2004; see also Kinnvall and Nesbitt-Larking 2011.

38 Kinnvall 2018; Steele and Homolar 2019.

39 Homolar and Scholz 2019.

40 Gülsah Çapan and Zarakol 2019.

41 Kinnvall 2019.

42 Browning 2019.

43 Browning 2018.

44 Mitzen 2018; Dingott Alkopher 2018.

45 Mälksoo 2018.

46 Mälksoo 2019.

47 Rumelili 2018; Subotic 2018.

48 Della Sala 2018.

49 Ibid., 267. 
of the EU's ontological security narratives than on inter-group ontological insecurity that arises from deep societal polarization over an ideological cleavage. ${ }^{50}$ The choice of label is, therefore, a matter of perspective and emphasis rather than of substance.

Polarization calls for a concept that emphasizes existential anxieties of both sides, and this paper, therefore, proposes the anxiety dilemma. This dilemma entraps groups of people with different identities and views of their social environment. Globalization and the liberal order provide cosmopolitans with ontological security but are a source of anxiety for communitarians. By contrast, strategies that communitarians employ to alleviate these anxieties are a source of anxiety for cosmopolitans. This see-saw effect, I argue, is a central feature of the current "age of anxiety." In analytical terms, a group, state, or region can be positioned differently vis-à-vis an overarching anxiety dilemma. They can belong to one of the poles (in present conceptualization, to communitarians or cosmopolitans); they can be neutral (not belong to either of the poles); or ambivalent (occupy a double or a middle position between the poles). The next section turns to discussing which of these positions the Western Balkans occupies.

\section{Locating the Western Balkans in the Present-Day Age of Anxiety}

The Western Balkan states have been affected by the various problems that have troubled the world and the EU in the past decade. The economic crisis and austerity, the migrant crisis, the rise in Eurosceptic parties, the Brexit, and the illiberal turn in Hungary and Poland have all caused the EU to experience "enlargement fatigue." Nonetheless, the Western Balkan states are still welcomed to join the EU, and they are formally working on doing just that. Their EU accession processes have never stopped, although they have been slower than anticipated. In late 2019, several member states led by France blocked the start of EU accession talks for Albania and North Macedonia. ${ }^{51}$ Their aim, however, was not to deny these countries EU membership. Instead, the decision was justified on the grounds that EU enlargement rules must be reformed before any new country is invited to start formal accession talks. And indeed, the EU member states reached a political agreement in March 2020 to finally open accession talks with the two countries. ${ }^{52}$ Additionally, North Macedonia officially joined NATO in the same month..$^{53}$ As for the Western Balkan countries that are already engaged in accession talks, namely Montenegro and Serbia, they have been successful in opening and closing many of the negotiating chapters, although the process has been rather sluggish.

Against this background, it is possible to argue that the Western Balkan states are not contesting the liberal (international) order. With EU membership talks at least formally

50 For polarization literature, see: McCoy and Somer 2019; Somer and McCoy 2018.

51 BBC 2019.

52 Davis 2020.

53 Mehta 2020. 
in place, few other states are under greater pressure to stay committed to liberal democracy. ${ }^{54}$ Therefore, concerning the anxiety dilemma, the Western Balkan states appear to align closer to cosmopolitans, a group defending the liberal (international) order. By extension, they seem to be a source of anxiety for those who are challenging this order.

However, other indicators paint a different picture. They show that EU conditionality and the willingness of the Western Balkan states to join the EU are not translating into increased democratization of the region. ${ }^{55}$ Over the past decade, powerful elites have assumed power in all the Western Balkan states. ${ }^{56}$ They have set up clientelistic systems allowing them to preserve their grip on political power, as well as to further their private economic interests. These elites are led by strong leaders who do not hesitate to use formal and informal tools to undermine democratic norms and the rule of law. Also, all Western Balkan governments extensively interfere in the media.

These trends point to a substantial democratic backsliding in the region. Freedom House now labels all the Western Balkan countries as "partly free." 57 The Economist Democracy Index sees them as either "flawed democracies" (Serbia), or as "hybrid regimes" (Albania, Montenegro, Macedonia, Bosnia and Herzegovina). ${ }^{58}$ The European Commission has also observed this trend. In its 2018 Enlargement Strategy, it stated that the Western Balkan countries "show clear elements of state capture, including links with organized crime and corruption at all levels of government and administration, as well as a strong entanglement of public and private interests." ${ }^{59}$ Finally, the scholarship is increasingly labeling Western Balkan governments as a case of competitive authoritarianism. ${ }^{60}$ Therefore, from the perspective of these indicators, these governments appear to be yet another case of the democratic backsliding and liberal order contestation observed globally. In terms of the anxiety dilemma, they thus belong more to the liberal order contesters than to its defenders. For the latter group, they are a potential source of anxiety.

With all this in mind, it can be argued that the Western Balkan states occupy an ambivalent position in the current anxiety dilemma. They do not legitimize themselves based on a strong ideological and rhetorical rejection of democracy and liberalism. On the contrary, most of them gained power and maintain it by promising to reform their respective countries in line with liberal-democratic norms. Their actions, however, tell a different story. They reveal a strong trend towards de-democratization in which elements of formal democracy are combined with informal authoritarianism.

54. Bieber 2020, 3.

55 Džankić, Keil, and Kmezić 2018.

56 Ibid., 2.

57 Freedom House 2019.

58 The Economist Intelligence Unit 2019.

59 European Commission 2018, 3.

60 For overview, see: Bieber 2020, 1-10. 
How did the Western Balkans come to occupy an ambivalent position in the present-day anxiety dilemma? How did it, to cite Milada Anna Vachudova, manage to be both behind the curve, and ahead of it ${ }^{61}$ I argue that the first set of reasons has to do with the distinctive sources of authoritarianism (including populism and nationalism) in the Western Balkans. Crucially, these sources are not the same as those theorized to explain the recent global trend towards communitarian ideologies and democratic backsliding. The current Western Balkan governments did not resort to authoritarianism and populism by offering relief from economic, political, and cultural anxieties caused by the liberal international order and its corollary-globalization. Quite the contrary, most of them gained power by promising to reform their respective countries in line with liberal-democratic norms. The source of their authoritarian tendencies is, therefore, local, and it has to do with the region's authoritarian history and ethnonationalism, including state- and nation-building projects. These local forces are what pulls the Western Balkan states towards the communitarian end of the anxiety dilemma.

But there are also forces that simultaneously pull them towards the cosmopolitan end, creating a peculiar mix of causes that place the region on both ends of the anxiety dilemma. One concerns the need for external legitimacy. In order to increase the chance of gaining or maintaining power, Western Balkan parties and leaders had to be recognized by the liberal-democratic actors, chiefly by the EU. This prompted them to adopt liberaldemocratic justification and pro-European orientation. Just as they began to adopt this strategy, the EU was hit by the prospect of democratic backsliding in several of its member states. Overwhelmed by internal problems, the EU changed its approach towards the region by prioritizing security over democratization. As a result, it granted legitimacy to Western Balkan governments, irrespective of numerous evidence indicating that they violate democracy.

In summary, I suggest that the confluence of four factors explain why the Western Balkans occupies an ambivalent position in the present-day anxiety dilemma. These are: (1) the region's authoritarian legacy and resulting political culture; (2) ethnonationalism coupled with state- and nation-building projects; (3) search for external legitimacy; and (4) the EU's abandonment of the long-held dictum of the inextricable link between peace and democracy. I discuss each in more detail by paying particular attention to the anxiety dynamics underpinning them.

\section{Authoritarian Legacy}

Many Western Balkan parties and leaders currently in power have a history of the authoritarian or authoritarian-leaning rule. The Serbian Progressive Party (SNS) and the Socialist Party of Serbia (SPS) both have roots in the 1990s. SPS was Slobodan Milošević's party. It ruled Serbia between 1990 and 2000 in an openly repressive manner, and it was

61 Vachudova 2019, 17. 
behind Serbia's numerous war engagements in the region. The party had to be removed from power through a large-scale popular protest. SNS was formed in 2008. However, it is an offshoot of the Serbian Radical Party (SRS), a right-wing nationalist party that was in coalition with SPS from 1998 until Milošević's overthrow in 2000. In Montenegro, the Democratic Party of Socialists (DPS) has been in power since 1990. DPS continues to embrace the structural intertwining of the state and the party it inherited from the Communist Party of Yugoslavia. The party's president, Milo Đukanović, has served six terms as the country's prime minister and two as its president. Albania's ruling party, the Socialist Party, is the successor of the Communist Party of Labor of Albania, Enver Hoxha's nationalist-communist party that controlled nearly every aspect of Albanian society for five decades.

With this in mind, the Western Balkans' democratic backsliding should not be read as a simple response to the anxieties caused by the deficiencies of the liberal international order and globalization. Rather, it should be read against the background of the region's political history and resulting political culture. Authoritarianism was a staple of Albanian and Yugoslavian communism (albeit to a different degree), and it carried over into their first post-communist decade. In this regard, it is a familiar style of rule, providing at least a portion of the region's societies with a sense of ontological security. Authoritarianism, therefore, can serve as an anxiety-alleviating tool. One anxiety to which it speaks is the region's slow post-communist transition. The Western Balkan states are not so much anxious about losing in the game of globalization, as much as they are anxious about never getting the chance to play the game fully. The current governments have embraced the goal of integrating their societies into the liberal international order and globalization processes by promising to do it better and faster than their democratic predecessors. However, this better and faster has included resorting to the familiar patterns of authoritarianism, the result of which is the mix of authoritarianism with the liberal-democratic justification that, ultimately, places the region at both ends of the anxiety dilemma. 


\section{Ethnic Tensions and State- and Nation-Building Projects}

Ethnic tensions coupled with post-communist state- and nation-building projects are another important local source of anxiety in the Western Balkans. Authoritarianism (a familiar style of rule) and nationalism (an identity-based anxiety-alleviating strategy), which jointly provoke the region's democratic backsliding, are much more a response to these anxieties than they are a response to the anxieties provoked by globalization and inherent deficiencies of the liberal international order. The local anxieties and maladaptive responses are thus the principal forces that pull the Western Balkans towards the communitarian side of the anxiety dilemma. This dynamic is particularly pronounced in Bosnia and Herzegovina, North Macedonia, Montenegro, and Kosovo.

Ethnonationalism has been a staple of politics in Bosnia and Herzegovina for the past three decades, with its most severe manifestation being an open conflict between Serbs, Bosniaks, and Croats in the early 1990s. ${ }^{62}$ Trapped in perceiving one another as a threat, each group's ethnonationalism acts as both a chief source of anxiety and a chief source of ontological security. Bosnian constitution, crafted after the war, was aimed at mitigating this reality. It was supposed to bring change through stabilization, to use Hansen's desecuritization type. It was supposed to prompt the three groups to abandon a dangerous security discourse by creating more space for political engagement. However, the constitution encourages these anxieties further. It establishes a three-person presidency intended to balance the political power of the three ethnic groups. At the same time, however, it incentivizes ethnonational politics: parties have a better chance of winning power if they orient themselves towards one of the ethnic groups than if they seek crossethnic support. ${ }^{63}$ On the one hand, this means that no single party can dominate Bosnia and Herzegovina. On the other, however, it means that each ethnic group is likely to have one dominant party. And indeed, each does: among Serbs, it is the Alliance of Independent Social Democrats (SNSD) led by Milorad Dodik; among Bosniaks, it is the Party for Democratic Action (SDA) led by Bakir Izetbegović; and among Croats, it is the Croatian Democratic Union of Bosnia and Herzegovina (HDZ) led by Dragan Čović. While each of the parties has shown authoritarian tendencies, Milorad Dodik and his SNSD seem to have gone the furthest. ${ }^{64}$

Since its independence, North Macedonia has suffered from two identity-related issues. One is the ethnic dispute between Macedonians and the sizeable Albanian minority. ${ }^{65}$ The other is the questioning of its statehood and nationhood: Greece disputed its name; Bulgaria, its language; and Serbia, the independence of its Orthodox Church. These issues made Macedonian ontological security inherently unstable. The first issue was addressed through a desecuritization strategy that here, too, most resembles Hansen's change through stabilization. After an open clash, the two sides signed a deal in 2001. The deal grants minority rights to Albanians and thus stabilizes the ethnic relations in the country, but it does not do away with their conflictual nature altogether. Their anxiety-inducing potential is a lingering feature of politics in North Macedonia. Greek denial of the country's name has been its most chronic statehood problem. For years, it prevented North 
Macedonia from progressing on its way towards the EU and NATO. The problem was resolved in 2018 when Macedonia became North Macedonia ${ }^{66}$ but the dispute kept the country in a state of anxiety for decades. The most striking anxiety-alleviating response came from Nikola Gruevski and his VMRO-DPMNE party, a center-right party with strong nationalist overtones responsible for North Macedonian democratic backsliding in the 2010s. Gruevski initiated antiquation campaign installing in Skopje and other Macedonian cities giant statues and monuments representing ancient Macedonian figures. ${ }^{67}$ The campaign aimed to identify present-day Macedonians with ancient Macedonians, thus resolving the country's post-communist identity anxiety. As expected, Greece did not welcome this move.

Montenegro has a sizable Serbian minority, $28.7 \% .^{68}$ This reality complicates its state and nation-building projects, as those who identify as Serbs never really wanted for Montenegro to split from Serbia. The ethnic tension between Montenegrins and Serbs is thus a source of anxiety in Montenegro. But, it is also an opportunity given that through Othering Serbs, Đukanovićs regime can postulate an ontologically stable Self for Montenegrins. The combination of authoritarian legacy and internal ethnic tensions thus points to local rather than global sources of Montenegrin authoritarian tendencies. This dynamic has been particularly visible in the country's 2019 Law on Religious Freedoms. ${ }^{69}$ The law requires all religious communities in the country to prove property ownership before 1918. The Serbian Orthodox Church in Montenegro accuses the state of threatening to appropriate its assets via the law, while Đukanović accuses the Church of promoting proSerbian policies to undermine Montenegrin statehood. ${ }^{70}$

Ethnic tensions and state-building are also the processes that put Kosovo at both ends of the anxiety dilemma. Handling the Serbian minority and Serbia's denial of its independence are among Kosovo's principal sources of anxiety. They prevent it from becoming a full state, capable of acting as a coherent political entity domestically, as well as internationally. At the same time, they push Kosovo's governments to continue to play the identity game as an anxiety alleviating strategy. This dynamic is amplified by the fact that many members of Kosovo's governments since independence are former members of the Kosovo Liberation Army (KLM). One of them is also Kosovo's current president, Hashim Thaçi. Still, it should be acknowledged that moves have been made to desecuritize the tensions. Among the most important are the minority rights granted to Serbs in Kosovo. The Serbian minority makes up only $5 \%$ of the Kosovo population, yet Serbian is now recognized as Kosovo's second official language, Serbs have ten guaranteed seats

66 Guardian 2018.

67 Vangeli 2011.

68 Mundi 2019.

69 Maksimović 2020.

70 Ibid. 
in the parliament, and they have to be represented in the government. ${ }^{71}$ Here, too, Hansen's change through stabilization is a good label to describe this desecuritizing move. Therefore, rather than resolving the tensions, minority rights have merely reduced them. Granting minority rights to Serbs is also a move by which Kosovo hopes to increase its international legitimacy. This brings us to the final factor that helps explain why the Western Balkans stands at both ends of the anxiety dilemma.

\section{Search for External Legitimacy}

As already indicated, leaders and parties responsible for the ongoing erosion of democracy in the Western Balkans have not gained power, or stayed in power, by disputing liberaldemocracy and globalization, but by doing just the opposite: by promising to reform their societies in such a way that they will finally become equal members of the liberal-democratic world. Political instrumentality is the primary reason for approach given that their autocratic and nationalistic tendencies do not allow for them to be classed as persuaded defenders of liberal democracy. Nevertheless, this approach enables them to exploit the anxiety of the Western Balkan people (or at least a portion of them) about being marginalized internationally, as well as the EU's anxieties about its immediate neighborhood becoming destabilized once more. The reward Western Balkan governments reap from this approach is legitimacy, in particular, external legitimacy. For this reason, it is possible to place them on the cosmopolitan side of the anxiety dilemma. Here are several prominent examples of this dynamic.

SNS split from the Serbian Radical Party due in large part to the failure of the Radicals to win power for over a decade despite enjoying sizable electoral support. One of the reasons for this failure was the international blocking of the Radicals, whose leader, Vojislav Sešelj, was an indicted war criminal at ICTY. The other reason was the substantial domestic majority in favor of Serbia's EU membership. To overcome these obstacles, two highly positioned SRS members, Aleksandar Vučić and Tomislav Nikolić, split from the party in 2008 and formed a new one. They abandoned Šeselj's dogmatic nationalism and war rhetoric and adopted a pro-EU stance. At the same time, they styled their new party as a European centrist party. Vučić branded himself as an energetic and pragmatic reformer regretful of his past. He showed readiness to grapple with problems that the previous pro-EU government stalled on, such as the problem of Kosovo and corruption. In 2013, the new government signed, under the EU auspice, the Brussels Agreement aimed at stabilizing relations with Kosovo. ${ }^{72}$ It also engaged in several high-profile symbolic gestures to signal its willingness to align with the Western values such as Vučić going to Srebrenica in 2015 to pay respect to the victims of the massacre committed by Bosnian Serb forces, ${ }^{73}$ and his decision to appoint in 2017 Ana Brnabić, an openly gay person, as Serbia's prime minister.

\footnotetext{
$71 \quad$ Bieber 2020, 72 .

72 Bieber 2015.

73 BBC 2015.
} 
Montenegro's decision to seek independence from Serbia, as well as the ensuing statebuilding project, required international support. As a consequence, after gaining independence in 2006, the Đukanović regime expressed its ambition to join the EU and NATO even more strongly than before. It, too, signaled its alignment with the West through a series of high-profile gestures such as the willingness to cooperate with the International Criminal Tribunal for the former Yugoslavia (ICTY), the early recognition of Kosovo's independence, and the harmonization of its foreign policy with the EU such as issuing sanctions to Russia following the 2014 Crimea annexation. ${ }^{74}$

In Macedonia, Nikola Gruevski became the country's prime minister by also branding himself as a pragmatic center-right pro-European reformist. This approach provided him with external legitimacy, which became particularly important to Gruevski and his VMRO-DPMNE in the run-up to the 2016 elections. A year earlier, the opposition leaked wiretaps documenting the government's widespread abuse of power. ${ }^{75}$ Fearing that the scandal might damage him, Gruevski secured the support of Sebastian Kurz, an Austrian foreign minister at the time. Kurz took part in VMRO-DPMNE's election rally, praising the party's program, its decision to stay committed to the EU, as well as its role in the closing of the Western Balkan migrant route. ${ }^{76}$ While Kurz's intervention did not translate into VMRO-DPMNE's victory, the fact that Gruevski saw it as important in diminishing the perception of the gravity of the wiretapping scandal is indicative. After all, the party did win nearly little over $38 \%$ of the votes in the 2016 snap elections. ${ }^{77}$

In Bosnia and Herzegovina, Kosovo, and Albania, a similar dynamic is also observable. Dodik's ascent to power was made possible by him styling himself as a young pragmatic reformer who was not involved in war crimes. ${ }^{78}$ Nowadays, however, he finds nationalism politically much more lucrative. In Albania, the Socialist Party opposed liberalization and democratization for a long time, only to embrace it as the only way to gain internal and external legitimacy. Finally, Kosovo, which is chronically dependent on Western support, has to engage in acts reflective of liberal-democratic values, an important one being the minority rights mentioned previously. 


\section{The EU's Prioritization of Stability Over Democracy}

To better understand the Western Balkans' ambivalent position in the present-day anxiety dilemma, we also need to consider the EU's perspective. Is the EU genuinely unaware that the region is experiencing democratic backsliding? The answer is no. As we have seen, the European Commission has already used the label "state capture" to describe the situation in the region. However, the use of this label has not (yet) translated into open delegitimization of the current Western Balkan governments. On the contrary, the EU often seems willing to turn a blind eye to their numerous undemocratic behaviors. This approach, I argue, can be understood as the EU's anxiety alleviating strategy. It, too, most resembles the strategy Hansen labeled change through stabilization.

The developments in the Western Balkans are a concern for the EU. However, they are a concern of lower priority. Unlike the Eurozone-crisis, the refugee crisis, Brexit, and the rise of populism and far-right politics, democratic backsliding in the Western Balkans is not threatening the EU's ontological security directly. In relative terms, it is a small threat to its identity and existence. Therefore, in order to dedicate more attention to the issues that directly threaten its ontological security, the EU seeks to keep its relations with the Western Balkans as stable as possible. It does so, as Hansen anticipated, by avoiding confrontational security discourse; that is, through desecuritization. This approach consists of prioritizing peace over democracy, and it includes legitimizing Western Balkan autocrats as long as they uphold peace. In the literature, this approach is increasingly known as stabilocracy. ${ }^{79}$

While this trade-off between stability and the neglect of authoritarianism helps the EU alleviate its central anxiety about the Western Balkans-the resurgence of the 1990s conflicts - it comes with a dangerous paradigm shift. Namely, it undermines the EU's foundational principle: the inseparability of peace and democracy. Throughout the 2010s, this link was a central dictum informing the Western Balkans' democratization. The leaders and parties with autocratic tendencies could not count on the EU's recognition. This legitimacy was granted only to those who espoused pro-European and anti-nationalist position. A party that was committed to the EU was automatically seen as democratic. This rationale, however, no longer holds. Most parties in the Western Balkans are now pro-European, even those with pronounced authoritarian tendencies. As these parties embraced this new position, the EU awarded them with legitimacy, implicitly accepting that there can, in fact, be peace without democracy.

It remains to be seen what the long-term consequences of this paradigm shift will be. In the short term, it might alleviate some of the EU's current anxieties. In the long run, however, it might do just the opposite as it fosters authoritarianism on the EU's periphery. For the time being, Western Balkan governments seem willing to play the game. They, too, engage in Hansen's strategy of change through stabilization. They reciprocate the EU's neglect of their authoritarianism by not exploiting the current divisions in the EU openly. Accordingly, rather than siding with populists in Hungary and Poland, they prefer 
to engage with the leaders who still espouse the EU's original values. For example, in 2017, Aleksandar Vučić visited German Chancellor Angela Merkel shortly before elections in Serbia. As already mentioned, ahead of Macedonian 2016 elections, Nikola Gruevski welcomed Austrian Chancellor Sebastian Kurz as a speaker in VMRO-DPMNE's rally. The reluctance to securitize refugees ${ }^{80}$ who were passing the so-called Balkan route is also telling of Western Balkan governments' willingness to recognize and be recognized by the "true" Europeans.

\section{The Western Balkans and the Local Anxiety Dilemmas}

Concerning anxiety, the internal and external behavior of Western Balkan governments differs markedly. Externally, as discussed previously, they seek to alleviate anxieties by trading stability for recognition. Internally, however, they are actively producing what can be labeled as the local anxiety dilemma. Manipulating existing and creating new anxieties, is, in many ways, the hallmark of their style of authoritarianism. It is how these governments ensure enough internal legitimacy to keep them in power for prolonged periods.

Just like the global anxiety dilemma, the local anxiety dilemma rests on societal polarization. Looking at the local anxiety dilemma and the polarization that underpins it is important because it qualifies the assertions made previously, namely, that authoritarianism, nationalism, and the search for external legitimacy have a different effect on different parts of the Western Balkan societies. They are not the universal tools of anxiety-production and anxiety-alleviation in the region. The ambivalent position of the Western Balkans in the global anxiety dilemma is thus not a simple result of navigating the space between the external need to appear liberal-democratic and ontological security tools that work domestically. It is also about the careful production of domestic tensions that create, exploit, and misrepresent the local cosmopolitan versus communitarian cleavage. The local anxiety dilemma is, therefore, nested in the global anxiety dilemma.

Therefore, polarization and the resulting local anxiety dilemma are an integral part of Western Balkan governments' handling of nationalism, opposition, real or manufactured crises, and the media. By actively seeking to polarize their respective societies, these governments split the electorate into those who are their persuaded supporters and those who see through their manipulation. The local anxiety dilemma thus consists of the former group seeing the governments as an anxiety-alleviating force, and the latter group seeing them as an anxiety-inducing force. The governments provide their supporters with stable cognitive frames and a sense of order. That is, they make them ontologically secure. The opposite is the case for the opponents. The governments are making their environment unstable, uncertain, and unpredictable, which, in turn, compromises their sense of identity and agency. A factor that has particularly contributed to this sense is the relationship between Western Balkan governments and the EU. The tradeoff the two have made 
between stability and recognition has, in effect, turned the world of the electorate and the parties opposing Western Balkan governments upside-down. They owned the pro-EU orientation and the EU support for a very long time. Without it, their sense of identity and agency are compromised. The ensuing sections outline how polarization strategies of Western Balkan governments work in creating this local anxiety dilemma.

\section{Polarization and Nationalism}

As indicated earlier, during the 1990s, Western Balkan regimes linked their authoritarianism closely to nationalism. Knowing that nationalism is a highly lucrative ideological resource, they used it to marginalize opposition and to justify democratic deficits. Today, they evoke nationalism considerably less. However, there are differences between the states. Roughly two groups can be distinguished. ${ }^{81}$ In the first group are Bosnia and Herzegovina and North Macedonia, where nationalism still plays a relatively significant role. The society in both states is divided along ethnonational lines, which, in recent past, were a source of open conflict. As a result, evoking nationalism in this context comes with strong existential undertones. It is used both as a tool of arousing ontological anxieties and of alleviating them.

Bosnian and Macedonian leaders also turn to nationalism to make sense of their countries' place in the international community. Both countries have encountered numerous obstacles on their way to joining the EU, and in the case of North Macedonia, also NATO. Each time the accession to these organizations became impossible or remote, they had to address the question of who they are and where they belong anew. Nationalism has been the usual answer. A particularly good example of this dynamic is the North Macedonian "antiquation campaign." As already indicated, the campaign consisted of the erection of gigantic statues of Alexander the Great and his father Philip in Skopje and other Macedonian cities. The campaign's purpose was to associate the present-day Macedonians with ancient Macedonians. Such an association was supposed to help build Macedonian nationhood following the dissolution of Yugoslavia. The "antiquation campaign" was controversial. It polarized Macedonia and contributed to the local anxiety dilemma. One part of the society welcomed the new identity frame, while the other was infuriated and confused by the scale of historical revisionism it included.

Serbia belongs to the second group of the Western Balkan countries, those in which nationalism has been somewhat downplayed. As discussed previously, SNS (Serbia's ruling party since 2012) and its leader Aleksandar Vučić have worked hard on crafting a new image. Vučić has openly referred to his nationalist past as a mistake. He has also made several gestures to back up this assertion such as visiting commemoration of 8000 Bosniak victims in Srebrenica. However, this does not mean that Vučić has abandoned nationalism altogether. It still uses it as an effective identity-based strategy to ensure the

81 Bieber 2020, 122. 
ontological security of at least one part of Serbian society. But there is a twist. Vučićs nationalist rhetoric has changed form. To use Hansen's terms, Vučić now employs strategies of replacement and rearticulation by which he seeks to provide an identity-based sense of ontological security but in a de-securitized form that diminishes anxiety. Throughout the 1990s and a good portion of the 2000s, Vučić's nationalism was based on representing the international community, and the West in particular, as a threat. He actively fostered the sense that "everybody is against us." Nowadays, however, his primary message is that "everybody respects us." In other words, Vučić has substituted the national discourse of victimhood with that of pride.

From the ontological standpoint, this reframing has resonated with the public because it is reminiscent of the discourse Tito used to position Yugoslavia during the Cold War divisions. It provides one part of the public with a familiar cognitive frame telling them who they are as a collective. All of this is not to say that Vučić has shunned a securitized type of nationalism completely. Mindful of the image it projects, his government has rather put this type of nationalism in the domain of plausible deniability. I will return to this issue below, where I discuss the role of media in polarizing the Western Balkan societies and thus in creating the local anxiety dilemmas.

\section{Polarization and Opposition Vilification}

The vilification of opposition is another polarizing strategy Western Balkan governments use to spur and ease anxieties in their respective societies. A particularly striking thing about this strategy is that the governments rarely denounced opposition on ideological grounds. Even if they wanted to do so, there is very little ideological difference that can be mobilized. Most of the mainstream parties in the Western Balkans are positioned around the political center, and most now have a pro-EU orientation. In their relationship with the opposition, Western Balkan governments, therefore, engage a strategy of Othering that overemphasizes a small rather than substantial difference. In so doing, they portray the opposition as violent, corrupt, criminal, and treacherous, and they do so by using existential frames. The opposition, they argue, threatens to disrupt their societies by various crooked activities, including collusion with alleged conspiratorial external forces such as George Soros. In short, Western Balkan governments often refuse to see the opposition as a legitimate political opponent. Instead, they label it as a source of anxiety, allowing them to argue that, without them in power, everything would collapse. Their regimes, they maintain, are indispensable for preserving the order. In other words, they are the gatekeepers of their society's ontological security. 


\section{Polarization and the Strongman Image}

Closely related to this dynamic is the idea of a strongman in power. All of the Western Balkan societies have leaders that embody their governments. This high level of political personalization results from the absence of coherent ideology paired with authoritarian tendencies. Western Balkan governments would struggle to legitimize themselves and survive if strong figures did not lead them. A news outlet survey conducted in 2014 suggests that $80 \%$ of SNS voters would not vote for the party if Vučić were not its leader. ${ }^{82}$ However, the personality of Western Balkan leaders is also highly polarizing. A part of their societies sees it as a source of stability; the other part, however, sees it as a source of anxiety and a sense of powerlessness.

The real and manufactured crises are a microcosm of this anxiety dilemma. The crises usually consist of the threat of an imminent coup, such as it happened in Serbia in 2015 ahead of Vučić's trip to China, and in Montenegro in 2016 on the election day. ${ }^{83}$ By resolving such crises, the governments are not only conveying a sense of relief that the leader is safe again but are also projecting an image of a state capable of preserving order. However, for those who oppose the leaders, a deep sense of uneasiness is fostered. They do not receive a message of a stable and strong state, but a message of a simulated and volatile state.

\section{Polarization and Media}

Western Balkan governments' chief instrument of polarization, and thus of creation of the local anxiety dilemma, is loyal media. There are two types of media in the region: concentrated (as in North Macedonia) and plural but with the increasing influence of tabloid journalism supportive of the government (as in Serbia and Montenegro). ${ }^{84}$ In both cases, however, spurring a generalized sense of anxiety and providing simplified narratives about the ongoing events are the main feature of media reporting. Government loyal media is, in essence, a conduit for nationalism, opposition vilification, and the projection of a strongmen image of the regimes' leaders. A distinctive feature of this type of media is that they always take things up a notch, meaning that they employ discourse that is unlikely to be used by the governments and their leaders. For example, Serbian tabloids regularly use derogatory terms for Bosniaks, Croats, and Albanians (Balije, Ustaše, and Šiptari, respectively). They also perpetually "warn" the public of imminent wars and coups. "They are preparing us a bloody Christmas-ISIS killer planning attacks on Serbian churches," reads one headline in Informer newspapers. ${ }^{85}$ The tabloids refer to "saviors" as well- "Putin: I

\section{$82 \quad$ N1 2014.}

83 It should be noted that, while the crisis in Serbia was manufactured, the one in Montenegro was real and complex, involving the former head of the Serbian special police unit, as well as Russian officers (e.g., see: Bechev 2018)

84. Bieber 2020, 124-129.

85 Informer 2017. 
will defend Serbs in Kosovo." ${ }^{86}$ They also run numerous articles about the opposition, accusing it of crime, corruption, lying, and stealing. Finally, the media is instrumental in cultivating an image of a strong Western Balkan leader. Analyses show that during the campaign for the 2017 presidential elections in Serbia, leading TV stations covered Vučić more than all other candidates combined.$^{87} \mathrm{TV}$ Pink, a popular private television, gave him $88 \%$ of candidate coverage, most of it positive. ${ }^{88}$

The reporting style of loyal media gives Western Balkan governments a plausible deniability card to fend off most of the criticism directed at them. For example, if the opponents accuse them of overt nationalism based on media reporting, they can always claim that they are not the ones who are engaging in such rhetoric but that it is the work of free and independent media. For those who are supportive of the government and who consume such media, the governments achieve the opposite effect. They give an impression of a state and nation under constant attack from the domestic and external powers (creating anxieties), and of a government that is capable of defending both (alleviating anxieties). In other words, to regime supporters, the regimes are still nationalistic enough. On the whole, Western Balkan media is in the business of spurring general anxieties, and, in so doing, feeding and perpetuating the local anxiety dilemmas.

Before concluding, a caveat is in order. The local anxiety dilemmas in the Western Balkans are not created only through polarization between persuaded government supporters and those who see through the government's manipulation. There is a third category of people, one that likely includes members of both of these groups, namely, people whose jobs depend on the government. All of the Western Balkan states have low employment rates. This reality makes the anxieties (even fears) of finding and keeping a job particularly pronounced. The ruling parties exploit these anxieties heavily. Capturing the state and reinforcing it with a clientelistic system is, in large part, a result of the manipulation of job-related anxieties. The ruling parties first took control of state resources. They then gave jobs to party members. Importantly, they did not provide only administrative positions but also lower-skilled jobs such as cleaning. Party loyalty is altogether valued more than skill and qualification. One only needs to look at the membership rates of the ruling parties in the Western Balkans to get a sense of this process. Between 2013 and 2016, the membership in Vučićs SNS increased from 350,000 to 600,000 people. ${ }^{89}$ Little more than $8 \%$ of the North Macedonian population has membership in Gruevski's VMRO-DPMNE..$^{90}$ In Montenegro, Đukanovićs DPS counts nearly $10 \%$ of the country's population. ${ }^{91}$ These high party membership rates are not a result of citizens' ideologi-

86 Ilić 2018.

87 BIRODI 2017.

88 Ibid.

89 Ristić 2018.

90 Jovanovska and Božinovska 2017.

91 Popović 2017. 
cal affiliation. They are, first and foremost, a transactional phenomenon: employmentrelated anxieties prompt citizens to trade party support for job security. The loyalty to the party, however, is not shown only through party membership and a vote for the party. Those who are party employees are also expected to attend various party events, including counter-protests, as well as to ensure several more votes for the party, most often from the members of their family.

\section{Conclusion}

The fall of communism in Yugoslavia and Albania occurred approximately at the same time as the fall of communism in Central and Eastern Europe. However, while Central and Eastern European countries started democratizing just about immediately, the Western Balkan countries were latecomers. Most of them took a few years, some even a whole decade, to truly embark on democratic reforms. Today, several Central and Eastern European countries, most prominently Poland and Hungary, are experiencing a democratic decline. The Western Balkan seems to be following a similar trend. But, there is again a mismatch between the two regions. While democratic backsliding in Central and Eastern Europe comes with a distinct illiberal turn and the questioning of European values, the democratic backsliding in the Western Balkans exhibits a kind of ideological ambivalence. The governments are still rhetorically employing liberal-democratic justification, mainly in connection to their formal efforts to join the EU. However, their ruling style is fraught with many autocratic tendencies. In addition to increasing corruption and clientelism, they heavily polarize their societies via media, the instrumentalization of nationalism, opposition vilification, and the manipulation of real and manufactured crises.

The paper has argued that this peculiarity of the Western Balkans, the coupling of liberaldemocratic justification with autocratic tendencies, places the region in the ambivalent position towards the anxiety dilemma underpinning the current age of anxiety. The Western Balkan countries are at the same time advocates of the liberal-order and globalization and actors that contribute to this order's destabilization. Accordingly, depending on the viewpoint, the region is either a source of ontological security or anxiety for sides engaged in the anxiety dilemma. One of the paper's contributions is therefore analytical. It shows that, despite the Western Balkans sharing many of the traits of other countries experiencing a democratic decline, it should not be lumped with them easily. The region exhibits specificities that are worth exploring for a better understanding of both global and local context. The application of the paper's analytical framework to other groups, states, and regions might reveal other specificities contributing to an overall more nuanced understanding of the present-day age of anxiety.

This brings me to the paper's theoretical contribution. By developing the concept of the anxiety dilemma to describe the present age of anxiety, the paper has attempted to further ontological security literature by paying attention to both sides that are engaged in the struggles over globalization and the liberal international order: cosmopolitans versus 
communitarians. The theoretical aim of the paper was to capture the anxiety dynamics of cross-cutting systemic polarization: cosmopolitans and communitarians are struggling both globally (e.g., democratic governments vs. populist governments) and domestically (e.g., democratic governments vs. populist opposition). As the example of the Western Balkans shows, internal anxiety dilemmas seem to be nested in the global anxiety dilemma. The paper has barely scratched the surface of this phenomenon. There is, therefore, space for further research and theorization. How does domestic polarization impact global polarization? Who is "us" and who is "them"? What kinds of anxiety-alleviating narratives are being developed in response to this cross-cutting polarization? These are just some of the questions that can be tackled with the further development of the concept of the anxiety dilemma. 


\section{References}

Ackermann, Alice. 2000. Making Peace Prevail: Preventing Violent Conflict in Macedonia. New York: Syracuse University Press.

Agius, Christine. 2017. "Drawing the Discourses of Ontological Security: Immigration and Identity in the Danish and Swedish Cartoon Crises." Cooperation and Conflict 52 (1): 109-125.

BBC. 2015. "Serbian PM Vucic Returns to Srebrenica Memorial after Attack." Accessed February 25, 2020. https://www.bbc.com/news/world-europe-34788014.

BBC. 2019. "Eu Blocks Albania and North Macedonia Membership Bids." Accessed February 10, 2020. https://www.bbc.com/news/world-europe-50100201.

Bechev, Dimitar. 2014. "Russia Sanctions: Balkan Countries React." South East Europe at LSE (blog). Accessed Jannuary 11, 2020. http://eprints.lse.ac.uk/80501/.

Bechev, Dimitar. 2018. “The 2016 Coup Attempt in Montenegro: Is Russia's Balkans Footprint Expanding?” Foreign Policy Research Institute. Accessed April 14, 2020. https://www.fpri.org/wp-content/uploads/2018/04/BechevFinal2018.pdf.

Beramendi, Pablo, Silja Häusermann, Herbert Kitschelt, and Hanspeter Kriesi. 2015. The Politics of Advanced Capitalism. Cambridge: Cambridge University Press.

Bieber, Florian. 2015. “The Serbia-Kosovo Agreements: An EU Success Story?” Review of Central and East European Law 40 (3-4): 285-319.

Bieber, Florian. 2018. “The Rise (and Fall) of Balkan Stabilitocracies." Horizons 10. Accessed April 14, 2020. https://www.cirsd.org/en/horizons/horizons-winter2018-issue-no-10/the-rise-and-fall-of-balkan-stabilitocracies.

Bieber, Florian. 2020. The Rise of Authoritarianism in the Western Balkans. London: Springer.

BIRODI. 2017. "Nalazi Monitoringa O Predstavljanju Vlade Srbije U Centralnim Informativnim Emisijama." 2017. Accessed February 3, 2020. http://www.birodi. rs/nalazi-monitoringa-o-predstavljanju-vlade-srbije-u-centralnim-informativnimemisijama/.

Blok, Anton. 1998. “The Narcissism of Minor Differences.” European Journal of Social Theory 1 (1): 33-56. 
Bornschier, Simon. 2010. Cleavage Politics and the Populist Right. The New Cultural Conflict in Western Europe. Philadelphia: Temple University Press.

Browning, Christopher S. 2018. "Brexit, Existential Anxiety and Ontological (in) Security." European Security 27 (3): 336-355.

Browning, Christopher S. 2019. "Brexit Populism and Fantasies of Fulfilment." Cambridge Review of International Affairs 32 (3): 222-244.

Browning, Christopher S., and Pertti Joenniemi. 2013. "From Fratricide to Security Community: Re-Theorising Difference in the Constitution of Nordic Peace." Journal of International Relations and Development 16 (4): 483-513.

Browning, Christopher S., and Pertti Joenniemi. 2017. “Ontological Security, Self-Articulation and the Securitization of Identity." Cooperation and Conflict 52 (1): 31-47.

Cupać, Jelena. 2012. “Ontological Security of International Organizations: NATO's Post-Cold War Identitycrisis and 'out-of-Area' Interventions.” СИНТЕЗИС 4 (1): $19-43$.

Cupać, Jelena. 2018. "It's Time for Behavioral and Emotional International Relations." Orders Beyond Borders WZB (blog). Accessed February 7, 2020. https://ordersbeyondborders.blog.wzb.eu/2018/09/18/its-time-for-behavioral-and-emotional-international-relations/.

Davis, Seana 2020. “EU Enlargement: Brussels 'Can Open Membership Talks' with Albania and North Macedonia.” Euronews, 2020. Accessed March 13, 2020. https:// www.euronews.com/2020/03/24/brussels-can-open-eu-membership-talks-withalbania-and-north-macedonia.

Della Sala, Vincent. 2018. "Narrating Europe: The EU's Ontological Security Dilemma." European Security 27 (3): 266-279.

Dingott Alkopher, Tal. 2015. “The Political Psychology of Integration Strategies: The Case of the European Commission's Interculturalism." Journal of International Relations and Development 18 (4): 428-454.

Dingott Alkopher, Tal. 2018. "Socio-Psychological Reactions in the EU to Immigration: From Regaining Ontological Security to Desecuritisation." European Security 27 (3): 314-335.

Džankić, Jelena, Soeren Keil, and Marko Kmezić. 2018. The Europeanisation of the Western Balkans: A Failure of EU Conditionality? London: Palgrave Macmillan. 
Erikson, Erik H. 1993. Childhood and Society. New York: WW Norton \& Company.

European Commission. 2018. Communication from the Commission to the European Parliament, the Council, the European Economic and Social Committee and the Committee of Regions: A Credible Enlargement Perspective for and Enhanced Eu Engagement with the Western Balkans. Accessed February 13, 2020. https://ec.europa.eu/ commission/sites/betapolitical/files/communication-credibleenlargement-perspective-western-balkans_en.pdf.

Freedom House. 2019. Freedom in the World 2019 Map. Accessed February 13, 2020. https://freedomhouse.org/report/freedom-world/freedom-world-2019/map.

Giddens, Anthony. 1991. Modernity and Self-Identity: Self and Society in the Late Modern Age. Cambridge, U.K.: Polity Press.

Gilens, Martin, and Benjamin I. Page. 2014. “Testing Theories of American Politics: Elites, Interest Groups, and Average Citizens." Perspectives on Politics 12 (3): 564581.

Gülsah Çapan, Zeynep, and Ayşe Zarakol. 2019. “Turkey's Ambivalent Self: Ontological Insecurity in 'Kemalism' Versus 'Erdoğanism.' Cambridge Review of International Affairs 32 (3): 263-282.

Hansen, Lene. 2012. "Reconstructing Desecuritisation: The Normative-Political in the Copenhagen School and Directions for How to Apply It." Review of International Studies 38 (3): 525-546.

Homolar, Alexandra, and Ronny Scholz. 2019. “The Power of Trump-Speak: Populist Crisis Narratives and Ontological Security." Cambridge Review of International Affairs 32 (3): 344-364.

Horwitz, Allan V. 2013. Anxiety: A Short History. Baltimore: The Johns Hopkins University Press.

Ilić, Marija R. 2018. "Putin: Braniću Srbe Na Kosovu." Republika: Portal Srpskog Telegrafa, 2018. Accessed on 17 February 2020. www.republika.rs/vesti/tema-dana/52252/putin-branicu-srbe-kosovu.

Informer. 2017. "Pripremaju Nam Krvav Božić- Isis Koljač Sprema Napade Na Srpske Crkve” Accessed on 13 February 2020. https://informer.rs/vesti/srbija/308775/ samo-informeru-pripremaju-nam-krvav-bozic-isis-koljac-sprema-napade-srpskecrkve. 
Inglehart, Ronald F, and Pippa Norris. 2016. "Trump, Brexit, and the Rise of Populism: Economic Have-Nots and Cultural Backlash.” Harvard Kennedy School: Faculty Research Working Paper Series.

Jovanovska, Slobodanka, and Žana P. Božinovska. 2017. Komparativna Studija Za Izbornite Nedostatoci Vo Makedonija I Iskustvata Vo Regionot. Centar za građanski monitoring. Accessed on 17 February 2020. https://www.mkd.mk/files/article/ 2017/11/17/studija.pdf.

Kinnvall, Catarina. 2004. "Globalization and Religious Nationalism: Self, Identity, and the Search for Ontological Security." Political Psychology 25 (5): 741-767.

Kinnvall, Catarina. 2018. "Ontological Insecurities and Postcolonial Imaginaries: The Emotional Appeal of Populism.” Humanity E Society 42 (4): 523-543.

Kinnvall, Catarina. 2019. "Populism, Ontological Insecurity and Hindutva: Modi and the Masculinization of Indian Politics." Cambridge Review of International Affairs 32 (3): 283-302.

Kinnvall, Catarina, Ian Manners, and Jennifer Mitzen. 2018. "Introduction to 2018 Special Issue of European Security: 'Ontological (in)Security in the European Union.' European Security 27 (3): 249-265.

Kinnvall, Catarina, and Jennifer Mitzen. 2017. "An Introduction to the Special Issue: Ontological Securities in World Politics.' Cooperation and Conflict 52 (1): 3-11.

Kinnvall, Catarina, and Paul Nesbitt-Larking. 2011. The Political Psychology of Globalization: Muslims in the West. Oxford: Oxford University Press.

Koneska, Cvete. 2019. "Ethnicisation Vs. Europeanisation: Promoting Good Governance in Divided States." In The Europeanisation of the Western Balkans: A Failure of Eu Conditionality?, edited by Jelena Džankić, Soeren Keil and Marko Kmezić, 135-155. London: Palgrave Macmillan.

Krahmann, Elke. 2018. “The Market for Ontological Security." European Security 27 (3): 356-373.

Kriesi, Hanspeter, Edgar Grande, Martin Dolezal, Marc Helbling, Dominic Höglinger, Swen Hutter, and Bruno Wüest. 2012. Political Conflict in Western Europe. Cambridge: Cambridge University Press.

Kriesi, Hanspeter, Edgar Grande, Romain Lachat, Martin Dolezal, Simon Bornschier, and Timotheos Frey. 2006. "Globalization and the Transformation of the National 
Political Space: Six European Countries Compared" European Journal of Political Research 45 (6): 921-956.

Kriesi, Hanspeter, Edgar Grande, Romain Lachat, Martin Dolezal, Simon Bornschier, and Timotheos Frey. 2008. West European Politics in the Age of Globalization. Cambridge: Cambridge University Press

Lyman, Rick. 2015. “Tiny Macedonia Confronts a Supersize Scandal." The New York Times, 2015. Accessed February 13, 2020. www.nytimes.com/2015/05/15/world/ europe/tiny-macedonia-confronts-a-supersize-scandal.html.

Maksimović, Sandra 2020. "Montenegrin Law on Religious Freedom: Polarization That Benefits the Government(S)?” European Western Balkans 2020. Accesed February 15, 2020. https://europeanwesternbalkans.com/2020/01/13/montenegrin-lawon-religious-freedom-polarization-that-benefits-the-governments/.

Mälksoo, Maria. 2018. "Countering Hybrid Warfare as Ontological Security Management: The Emerging Practices of the EU and NATO." European Security 27 (3): 374-392.

Mälksoo, Maria. 2019. "The Normative Threat of Subtle Subversion: The Return of 'Eastern Europe'as an Ontological Insecurity Trope." Cambridge Review of International Affairs 32 (3): 365-383.

Manow, Philip. 2018. Die Politische Ökonomie Des Populismus. Berlin: Suhrkamp Verlag.

McCoy, Jennifer, and Murat Somer. 2019. “Toward a Theory of Pernicious Polarization and How It Harms Democracies: Comparative Evidence and Possible Remedies." The Annals of the American Academy of Political and Social Science 681 (1): 234-271.

Mehta, Aaron. 2020. "North Macedonia to Officially Join NATO on Friday." Defense News, 2020. Accessed March 16, 2020. https://www.defensenews.com/global/europe/2020/03/24/north-macedonia-expected-to-join-nato-within-days/.

Mitzen, Jennifer. 2006a. “Anchoring Europe’s Civilizing Identity: Habits, Capabilities and Ontological Security." Journal of European Public Policy 13 (2): 270-285.

Mitzen, Jennifer. 2006b. “Ontological Security in World Politics: State Identity and the Security Dilemma." European Journal of International Relations 12 (3): 341-370.

Mitzen, Jennifer. 2018. “Anxious Community: EU as (in) Security Community." European Security 27 (3): 393-413. 
Mouffe, Chantal. 2018. For a Left Populism. New York: Verso Books.

Mudde, Cas, and Cristóbal Rovira Kaltwasser. 2012. Populism in Europe and the Americas: Threat or Corrective for Democracy? Cambridge: Cambridge University Press.

Mundi Index. 2019. “Montenegro Demographics Profile 2019.” Accessed February 15, 2020. https://www.indexmundi.com/montenegro/demographics_profile.html.

N1. 2014. "Istraživanje: SNS Bez Vučića Bi Imao 80 Odsto Manje Glasova." Accessed on 18 February 2020. http://rs.n1info.com/Vesti/a21521/Istrazivanje-SNS-bezVucica-bi-imao-80-odsto-manje-glasova.html.

Pavlović, Srđa, 2016. “Montenegro's 'stabilitocracy': The West's support of Đukanović is damaging the prospects of democratic change." LSEE Blog. Accessed April 13, 2020. https://blogs.lse.ac.uk/europpblog/2016/12/23/montenegros-stabilitocracyhow-the-wests-support-of-dukanovic-is-damaging-the-prospects-of-democraticchange/.

Popović, Tina 2017. "Svaki Sedmi Građanin CG Ima Člansku Kartu Jedne Od Šest Partija Koje Postoje Najmanje 10 Godina.” Vijesti, 2017. Accessed February 17, 2020. www.vijesti.me/vijesti/politika/svaki-sedmi-gradanin-cg-ima-clansku-kartu-jedneod-sest-partija-koje-postoje-najmanje-10-godina.

Primatarova, Margarita, and Johanna Deimel. 2012. "Bridge over Troubled Waters? The Role of the Internationals in Albania." Centre for Liberal Strategies. Accessed April 17, 2020. http://www.cls-sofia.org/uploads/files/Bridge\%20Over\%20 Troubled\%20Waters_The\%20Role\%20of\%20the\%20Internationals\%20in\%20Albania. pdf.

Ristić, Irena. 2018. "Serbia-a Regime That Only Seemed Gone." In Illiberal and Authoritarian Tendencies in Central, Southeast and Eastern Europe, edited by Bieber Florian, Magdalena Solska Solska and Dane Taleski, 150-166. Bern: Peter Lang.

Rumelili, Bahar. 2018. "Breaking with Europe's Pasts: Memory, Reconciliation, and Ontological (in) Security." European Security 27 (3): 280-295.

Šabić, Senada Šelo. 2017. "The Impact of the Refugee Crisis in the Balkans: A Drift Towards Security." Journal of Regional Security 12 (1): 51-74.

Solomon, Ty. 2018. "Ontological Security, Circulations of Affect, and the Arab Spring." Journal of International Relations and Development 21 (4): 934-958. 
Somer, Murat, and Jennifer McCoy. 2018. "Déjà Vu? Polarization and Endangered Democracies in the 21st Century." American Behavioral Scientist 62 (1): 3-15.

Steele, Brent J, and Alexandra Homolar. 2019. "Ontological Insecurities and the Politics of Contemporary Populism." Cambridge Review of International Affairs 32 (3): 214-221.

Steele, Brent J. 2008. Ontological Security in International Relations: Self-Identity and the IR State. London: Routledge.

Subotić, Jelena. 2018. "Political Memory, Ontological Security, and Holocaust Remembrance in Post-Communist Europe." European Security 27 (3): 296-313.

Teney, Céline, Onawa Promise Lacewell, and Pieter De Wilde. 2014. "Winners and Losers of Globalization in Europe: Attitudes and Ideologies." European Political Science Review 6 (4): 575-595.

The Guardian. 2018. "Welcome to North Macedonia: Parliament Votes for Name Change." Accessed February 13, 2020. https://www.theguardian.com/world/2018/ oct/20/welcome-to-north-macedonia-parliament-votes-for-name-change.

Toal, Gerard. 2013. “'Republika Srpska Will Have a Referendum': The Rhetorical Politics of Milorad Dodik." Nationalities Papers 41 (1): 166-204.

Vachudova, Milada Anna. 2019. "EU Enlargement and State Capture in the Western Balkans: A Failure of EU Conditionality?” In The Europeanisation of the Western Balkans, edited by Jelena Džankić, Soeren Keil and Marko Kmezić, 63-85. London: Palgrave Macmillan.

Vangeli, Anastas. 2011. "Nation-Building Ancient Macedonian Style: The Origins and the Effects of the So-Called Antiquization in Macedonia." Nationalities Papers 39 (1): $13-32$.

Veljanova, Hristina. 2016. The Republic of Macedonia's 2016 Parliamentary Elections Handbook. Skopje: The Konrad Adenauer Stiftung. 